\title{
20 Yıl Sonrasında Hiyerarşik Boş Zaman Kısıtlar Teorisini Değerlendirmek
}

Assessing Hierarchical Leisure Constraints Theory after Two Decades ${ }^{1}$

\author{
Geoffrey GODBEY*, Duane W. CRAWFORD**, Xiangyou Sharon SHEN ${ }^{* * *}$ \\ * The Pennsylvania State University \\ ** Texas Tech University \\ *** The Pennsylvania State University
}

Türkçeye çeviren:

Kamil YAĞCI ****

**** Yrd. Doç. Dr., Pamukkale Üniversitesi, Turizm Fakültesi, Turizm Rehberliği Bölümü, 20030, Denizli, Türkiye.

E-posta: kyagci74@yahoo.com

\section{MAKALE BILGILERI}

Anahtar sözcükler:

Hiyerarşik boş zaman kısıtlar teorisi, Boş zaman kısıtları, Kısıt araștırmalarının gözden geçirilmesi, ampirik doğrulama.

\begin{abstract}
ÖZ
Bu makale hiyerarsik bos zaman kısıtlar teorisinin (Crawford ve Godbey 1987; Jackson ve Godbey 1991) durumunu birçok yönden değerlendirmeye yöneliktir. Ele alınan konulardan bazıları orijinal modelin bazı yönlerinin açıklığa kavuşturulması ve detaylandırılması, modelden yararlanan ya da inceleyen çalışmaların ne derece doğrulayıcı oldukları bakımından değerlendirilmesi, çeşitli yazarlar tarafından orijinal modele yöneltilen eleştiriler ve gelecek çalışmalar için olasılıklardır. Varılan sonuçlara göre; modelin kültürlerarası kullanıma uygun olduğu, modelin bos zaman değerlendirmeden başka davranışları incelemek amaçlı kullanılabileceği, günümüze kadar yapılan çalışmalar her ne kadar doğrulayıcı nitelikte olsalar da boş zaman kısıtlar teorisinin bir sonraki basamağa taşınabilmesi için önemli bir potansiyele sahip olduğu görülmektedir.
\end{abstract}

\section{ABSTRACT}

This article assesses the status of hierarchical leisure constraints theory (Crawford \& Godbey, 1987; Crawford, Jackson, \& Godbey 1991) regarding many issues. Such issues include clarification and elaboration of some aspects of the original model, a review of studies which have used or examined the model and the extent to which they are confirmatory, critiques of the original model by various authors, and avenues for further research. Conclusions drawn include that the model is cross culturally relevant, that the model may examine forms of behavior other than leisure, and that, while research to date has been largely confirmatory, there is a high potential for the theory to be expanded in order to advance leisure constraints research to the next level.

\section{Key words: theory, Leisure constraints, Reviez validation}

\section{Giriş}

Hiyerarşik boş zaman kısıtlar teorisi modelleri ilk olarak bundan yaklaşık 20 yıl önce Crawford ve Godbey (1987) ve Crawford, Jackson, Godbey (1991) tarafından sunulmuş ve ardından Jackson, Crawford ve Godbey (1993) tarafından genişletilerek, boş zaman davranışlarının incelenmesine yardımcı olan önemli bir araç olarak kabul görmüştür. Bu modeller birlikte ele alındığında, aslında

\footnotetext{
1 "Godbey, G., Crawford, D. W., ve Shen, X., S. (2010)."Assesing Hierarchical Leisure Constraints Theory after Two Decades", Journal of Leisure Research, 42 (1): 111-134." künyesini taş1yan makaleden dergi yayıncısının izni alınarak çevrilmiştir.
}

verilen her bir modelin gerekli olarak denenebilir yeni sav ve öneri kümeleri varsaydığı, boş zaman kısıtlar hiyerarşik teorisi olarak neyin daha iyi tanımlanabileceğini ihtiva etmektedirler. Bu üç modelin her biri soyut kavramsallaştırma olarak tartışılabilmesine rağmen aslında kısıtları boş zaman davranışları teması olarak ele alan daha soyut teorik yönelimin üç gözlemlenebilir göstergeleridir. Teknik olarak sadece teorilerin test edilebilinecegi, modellerin de genel olarak metafor ve örnekseme türlerinden birisinden biçimleneceği ve doğrudan test edilemeyeceğinin farkında olmamıza rağmen bu çalışmada 'model ve teori' kavramları zaman zaman birbirlerinin yerine kullanılmıştır. Son yir- 
mi yılda boş zaman kısıtlarının doğası ve fonksiyonları ile ilgili kavramların geliştirildiğinin ve bu formülleştirmelerin boş zaman ilgi alanını engelleyecek şekilde farklı bakış açıları haline geldiğinin farkındayız. Bununla birlikte bu makalede, boş zaman davranış kısıtlamalarının hiyerarşik olarak düzenlenmesinin önerildiği hiyerarşik boş zaman kisitlar teorisinin 1991 (Crawford, Jackson ve Godbey 1991) yinelemesine odaklandik.

Bu modeller, boş zaman kısıtlar teorisinin üç temel bileşimi olarak görüldüğünde, boş zaman "engelleri" hakkında var olan bakış açılarından önemli ayrılıkları ve aynı zamanda birkaç yılda hızlı bir şekilde bir araya gelmiş birbiriyle ilişkili düşünce kümeleri teşkili teorisinin basamaklarını temsil ederler. Bu düşünceler dikkat çekmeye ve yorum almaya devam etmektedir. Buna karşın daha önemlisi kısıtlar teorisi son yirmi yılda yapılan araştırmaların önemli bölümü için temel olarak hizmet etmiştir. Bundan dolayı bu noktaya nasıl geldiğini anlamak ve sonraki yirmi yıla nasıl daha yararlı şekilde ilerleyeceğini mevcut durumla sorgulamak için iyi bir zaman olduğunu düşünüyoruz. Halen devam etmekte olan çalışmaların sonuçları sürpriz bir şekilde hoşumuza gitmeyecek şekilde çıkabilir, bunun nedeni, devam eden araştırmaların kökenlerini yeniden değerlendirmek tehlikeli bir girişim olarak değerlendirilebilir, bununla beraber bu durum (a) orijinal modelin yönlerini açıklığa kavuşturmak ve ayrıntılarına girmek (b) çalışmaları modeli kullanarak gözden geçirmek ve Kuzey Amerika ve çoklu kültürlerde, modelden türeyen öngörülerin kapsamını teyit etmek (c) modelin eleştirilerini incelemek ve (d) gelecek çalışmalar için bazı olası öneriler sunmak için bize iyi bir fırsat sunuyor.

\section{TEORININ ÖZELLIKLERI}

1987 yılında tanıtılan orijinal teori, boş zaman değerlendirme faaliyetlerini teşvik eden ve engelleyen faktörler hakkındaki modern düşünceye yönelik analiz seviyeleri boyutlarını ortaya koymuştu (Crawford ve Godbey 1987). Böyle yaparak bireysel, bireylerarası (ikili ve daha fazla) ve bağlamsal analiz seviyeleriyle örtüşen içe donuk, bireylerarasi ve yapısal kısitların teorik yapısını ortaya koyduk. Orijinal model kısıtlar ve boş zaman aktivite tercihleri ve müteakip boş zaman etkinlikleri arasındaki ilişkilerin tanıtılması ve açıklanmasıyla ilgilidir; öyle ki bu kısıtlar, durumsal aktivite tercih- leri (bireysel), tercihler ve katılımların her ikisiyle de alakalı (bireylerarası) veya tercih-katılım ilişkisi arasında, farazi önermenin koşullu parçası olarak görülür. 1991 hiyerarşik modeli, en yakınsaldan (bireysel) en ıraksağa (yapısal) hiyerarşik olarak dizilen üç teoriyi birbirine bağlayarak başlangıçtaki teoriyi genişletir (Crawford, Jackson, Godbey 1991). 1993 modeli nihai boş zaman davranışının, bu kısıtlar seviyelerinin ardışık olarak başarılı uzlaşmalarına dayalı olduğunu ileri sürer (Jackson, Crawford, Godbey 1993). Bundan dolay1; modellerdeki değişikliklerle birlikte faktörler arasındaki karşılıklı ilişkileri ve bundan dolayı teorideki süreçleri nasıl gördügüümüzdeki değiş̧iklikleri yansıtan kısıtlar teorisinin temel ögeleri bu döngü içinde durağan kalmışlardır.

\section{Hiyerarşik Boş Zaman Kısıtlar Teorisi Üzerine Ampirik Araştırmalar}

Başlangıcından bu yana, hiyerarşik boş zaman k1sitlar teorisi modeli (Crawford vd. 1991) fazlasiyla dikkat çekmiştir (Jackson 2005; Jackson ve Scott 1999) ve (a) modeli ana temel rehber teorik çerçeve olarak kullanan (örnek olarak, Burns ve Graefe 2007; Elkins 2004; Gilbert ve Hudson 2000; Han 2004; Nyaupane, Morais ve Graefe 2004; Nyaupane ve Andereck 2008; Oh 2005; Pennington-Gray ve Kerstetter 2002; Young, Ross ve Barcelona 2003; Raymore, Godbey ve Crawford 1994; Walter, Jackson ve Deng 2007) ya da (b) ampirik doğrulamaya özne olarak kullanan birçok araştırmaya (örnek olarak, Raymore, Godbey, Crawford ve Von Eye 1993; Alexandris, Grouios, Tsorbatzoudis ve Bliatsou 2001; Hawkins, Peng, Hsieh ve Eklund 1999) ilham kaynağ 1 olmuştur. Hiyerarşik boş zaman k1sıtlar modelini, üç boyutlu boş zaman kısıtları kavramı, modelle ilişkili üç sav ve bunlardan çıan öngörüleri de kapsayacak şekilde, çevreleyen 20 yıllık ana deneysel çalışmaları gözden geçireceğiz.

\section{Boş Zamanlar Kısıtları Boyutsallığı ve Öıçüm Sorunları}

Hiyerarşik model, boş zaman kısıtlarının gerçekleşmesi veya sürecin ilerlemesi için sırasıyla izlenmesi gereken üç seviye olduğunu belirtir: bireysel, bireylerarası ve yapısal. Üç seviyeye bağlı kalacak şekilde kısıtların çeşitlerini doğrudan veya dolaylı olarak tanımlayan birçok araştırmanın yanı sıra üç seviyeli kısıtların farklı kategori veya yapılar 
oluşturup oluşturmadığını birçok araştırmacı test etmektedir. Örneğin Raymore vd. (1993) doğrulayıcı faktör analizini kullanarak üç boyutlu yapının geçerliliğini göstermişlerdir. Onların sonuçları üç alt grubun varlığının gösterilmesini destekleyen ön kanıtlar sağlamıştır. Benzer şekilde Hawkins vd. (1999), Hubbard ve Mannell (2001) ve Nyaupane vd. (2004) farklı madde gruplarıyla üç boyutlu modeli tekrar etmişlerdir.

Bununla birlikte boyutsallık durumu çeşitli sebeplerden dolayı ilk bakışta göründüğünden çok daha karmaşıktır. Özellikle üç seviyeyi oluşturan faktörler arasındaki etkileşimler gözlemlendiğin$\mathrm{de}^{1}$, bu faktörlerin her birinin ayrı kategoriler olarak görülüp görülmeyeceği sorusu ortaya çıkmaktadır. Auster (2001) örneğin içsel kısıtların bireyin içinde tanımlanmasını sorgulamıştır çünkü birçokları toplum tarafından etkilenen veya toplumdan kaynaklanan kökenlere sahiptir (Bkz. Philipp 1995). Benzer şekilde Shaw ve Henderson (2005) bakım etiği ve yetki vermeden kaçınmanın -içsel seviye faktörleri- kadınları bakım ile ilgili faaliyetleri boş zamandan daha öncelikli olarak değerlendirmelerine, bunun sonucu olarak ta en azından kısmi olarak boş zaman faaliyetlerine zaman ay1ramamaya -yapisal bir kisit- yöneltmektedir. Diğer araştırmacılar (örnek olarak, Gilbert ve Hudson 2000; Scott ve Munson 1994) içsel, bireylerarası ve yapısal kısıtlar arasındaki olası etkileşimlerden bahsetmişlerdir. Bu tartışmalar, modelin doğrusal hiyerarşik varsayımına meydan okuyan iç içe geçmiş ilişkileri önermiş gibi görünmektedir. Bir sonraki bolümde bu konuyu daha ayrıntılı inceleyeceğiz. Burada, kavramsal olarak farklı yapıların bağlantılı olabileceğini (birçok faktör, faktör analiz çözümünde ilintili olabilir) akıldan çıkarmadan bu tur kanıtları kullanarak boyutsallığ sorulara cevap vereceğiz. Aslında sosyal yaşamla bağlantılı ilgili değişkenlerin (veya faktörlerin) ta-

\footnotetext{
${ }^{2}$ Etkileşim kavramı yerine "örtüşme" kavramı sıklıkla bu tip tartışmalarda kullanılmaktadır. Ancak, bu tartışmalara kaynaklık yapan ampirik bulgulara dayanarak "etkileşim" kavramının daha uygun olduğunu düşünmekteyiz: Bahsi geçen üç tür kısit hakkındaki algılar birbirlerini etkileyebilirler ya da altlarında yatan sebepler örtüşebilirler. Başka bir deyişle, belirli bir seviyedeki kısıtların (bir içsel kısıt gibi) ortaya çıkmasına neden olan faktörler farklı bir seviyede yer alabilirler (bir toplumsal seviye faktörü olan kısıtlayıcı sosyal kurallar gibi). Ancak, kısıt kategorileri kavramsal olarak tartışmaya yer bırakmayacak şekilde açıktır.
}

mamen bağımsız olduğunu söylemek makul değildir. Bunun güzel örnekleri boy ve kilo, sıcaklık ve yüzmeye giden kişi sayısı veya tüketilen dondurma vb. olarak görülebilir ki bunlar aslında farklı ama bağlantılı kavramlardır. Bizim durumumuzda, kantitatif çalışmalar üç boyutlu kısıtlar arasındaki korelasyonu ortaya koymaktadır. (örneğin Raymore vd. 1993 ortadan yükseğe doğru: $r=0,42-0,695$ ve \%16-\%49 arasında değişen paylaşılan varyansa işaret eden korelasyonlar bulmuşlardır) ama bu bulgu yapılar arasında farklılığın olmadığının belirtisi olarak alınmamalıdır (bazı çalışmalarda öyle olsa bile). Bunun yerine yapıların teorik olarak, interaktif süreçlerle veya altında yatan müşterek sebeplerle tam da yukarıda bahsedilen çalışmaların önerdiği gibi bağlı olabileceğini gösterebilir.

Bu bağlamda, her bir kategoride homojenliklere şüpheyle yaklaşan her bir üç alt skala için içsel tutarlılıklar acısından düşük güvenilirlikler (örneğin alpha $=0.42-0.55$ Hubbard ve Mannell 2001) bildirilmiştir. Hubbard ve Mannell ile hiyerarşik modeldeki her bir kategorideki belirli kısitların ister istemez heterojen ve birbirleriyle güçlü bir korelasyona sahip olmayabilecekleri konusunda hemfikiriz (örneğin her bir kategorinin öz ilgi alanı çok geniş olabilir). Örneğin, boş zaman faaliyetlerinin uygunluğunun negatif öznel değerlendirmesi sonucundaki içsel kısıtlarla "(algılanan) kişisel beceriler eksikliğinden" kaynaklanan içsel kısıtlar arasında yüksek korelasyon beklemek gerçekçi olmayacaktır (örneğin “ben güçlüyüm, esneğim ve çok iyi bir boksör olabileceğimi düşünüyorum ama yapmayacağım çünkü bu kadınlar için uygun bir aktivite değil) veya benzer şekilde "zamansızlıktan" kaynaklanan yapisal kısıt ile rekreasyon alanlarına ulaşabilme arasında yüksek korelasyon beklememek gerekir (Nyaupane vd. 2004). Bundan dolayı eğer üç kategori kesin şekilde yapının üç boyutu olarak işlevselleştirilebilecekse, düşükten orta seviyeye kadar iç tutarlılıklar beklemeliyiz. Bu durumun iki sonucu ortaya çıkar (a) hiyerarşik modeli çerçeve olarak kullanan yapılar geliştirirken ifade seçiminde yüksek iç tutarlılıklar, kabul edilebilir güvenilirlik ve model uyumu için kapsam geçerliliğinden feda edilerek, körü körüne aranmamalıdır (örneğin diğerleriyle benzeşmeyen ifade dışarıda bırakılmalıdır) ve (b) her bir kategori içerisinde üç boyutlu çerçevede ikincil sıra faktörleri geliştirmek ve alt boyutları araştırmak daha uygun olabilir. İkinci yöndeki 
çalışmaların başladığını görmekten mutluluk duymaktayız (örneğin Nyaupene ve Andereck 2008; Walker vd. 2007).

Dahası homojenlik konusunda ikinci bir nüans mevcuttur, adlandırmak gerekirse değişen boş zaman faaliyetlerinin doğasıyla (örneğin spora karşın sanat beğenisi, dışarıda yapılanlara karşı ev içi faaliyetleri), çalışılan örneklemin farklı karakteristikleri (örneğin yaş, cinsiyet, fiziksel ve zihinsel kabiliyet, aile hayatı döngüsü, etnisite vb.) ve değişik katılım seviyeleri (örneğin yeni bir boş zaman faaliyeti, mevcut durumdan daha yüksek veya istenen seviyeye doğru uzmanlık veya kalite deneyimini aramak, vb.) ile ilişkili çok farklı kısıt mevcuttur. Birçok araştırmacı bu durum hakkında bilgi sahibidir ve bazıları faaliyet, anakütle veya belirli temel özellikli yaklaşımların savunuculuğunu yapmaktadır (bkz., Clayton 2002; Hawkins vd. 1999; Hultsman 1993; Jackson 1994, 2005; Jackson ve Dunn 1991; Jackson ve Rucks 1995; Jackson ve Scott 1999; Mannell ve Loucks-Atkinson 2005; Nadirova ve Jackson 2000; Nyaupane vd. 2004; Searle ve Brayley 1992). Aslında, genel yaklaşım her bir araştırma grubunun belirli bir araştırma çerçevesine ve/veya ihtiyaca göre özelleştirilmiş enstrümana göre kısıt kategorileri tanımlamasıdır (örnek olarak, Alexandris ve Carroll 1997a; Arab-Moghaddam, Henderson, ve Sheikholeslani 2007; Backman 1991; Backman ve Crompton, 1989, 1990; Brown, Brown, ve Hansen 2001; Dunlop 2006; Frederick ve Shaw 1995; Gilber ve Hudson 2000; Harrington 1991; Henderson ve Ainsworth 2000; Henderson, Bedini, Hecht, ve Shuler 1995; Hultsman 1995; James 2000; Lee ve Tideswell 2005; Lu 2006; McCarville ve Smale 1993; Norman 1995; Petrick, Backman, Bixler, ve Norman 2001; Philipp 1995; Scott ve Munson 1994; Stodolska 1998; Tian, Crompton, ve Witt 1996; Tsai ve Fung 2005; Williams ve Fidgeon 2002; Wright ve Goodale 1991; Wright ve Backman 2001; Xiong 2007; Zhang 2007). Sonuç olarak kısıtları ölçebilmek için standart bir ölçek bulunmamaktadır (Hubbard ve Mannell 2001). Araştırma sırasında araştırılan fenomene bağlı kalmak ve deneklerin alg1 ve deneyimlerine duyarlı olmaya yardım etmek açısından yerelleştirilmiş yaklaşımların önemini biliyoruz. Bununla birlikte iki noktaya dikkat etmek gerekmektedir. Birincisi, bu yaklaşımın avantajları, bizim ikinci husustaki görüşümüzün ana fikrini de oluşturan, belirli bir teorik te- meli olmadan veriye dayalı araştırmanın onaylanması için kullanılmamalıdır. Belirli bir ortak teorik çerçeveyi temel almayan veya var olan çalışmaların verilerini kullanan (özellikle değişik alt alanlardan gelen) yerel parça parça araştırma uygulamaları çalışmalar arası karşılaştırmaları zorlaştırmakta ve bunun sonucunda bu alana bilgi transferini ve birikimini zorlaştırmaktadır. İki durumdan da kaçınabilmek için, "araştırmacıların ihtiyaçlarına göre düzenleyebilecekleri bir kısıtlar havuzu oluşturmak yararlı olabilir" diyen Hubbard ve Mannell (2001) in önerisini destekliyoruz. Eşit olarak inanıyoruz ki hiyerarşik boş zaman kısıtlar modeli (Crawford ve Godbey 1987; Crawford vd. 1991) ve onun önemli uzantısı olan kisit inkar teorisi (Jackson vd. 1993) kısıtların ve bağlantılı olguların sistematik olarak araştırılmasında deneyimsel çerçeveye hizmet edebilir. Araştırmacılar bu çerçeveyi, boş zaman faaliyetleri ve katılımcıların doğası ve karakteristiklerini dikkate alacak şekilde geniş bir kısıtlar listesi geliştirmede iyi bir başlangıç noktası olarak kullanabilirler (bkz., Auster 2001; McQuarrie ve Jackson 1996). Bu yaklaşım birçok ampirik çalışmada başarılı bir şekilde uygulanmıştır (örneğin, Elkins 2004; Han 2004; Hubbard ve Mannell 2001; Kohlleppel 2002; Nyaupane ve Andereck 2008; Nyaupane vd. 2004; Oh 2005; Raymore, Godbey ve Crawford 1994; Walker vd. 2007).

Ek bir bilgi olarak, çoklu popülasyonlar arasında (kültürler arası çalışmalar gibi) boş zaman kısıt ölçümlerinin karşılaştırılabilirliği ya da değişik çalışmalar için kısıt enstrümanlarını ödünç alma/deneme çalışmaları yapacak araştırmacılara bahsi geçen üç seviyeyi dikkatli bir mantıksal sıralamayla ayırt etmelerini öneriyoruz. İlk olarak araştırmacılar k1sıtları, gruplar arasında içeriklerine ya da türlerine göre karşılaştırılabilirliğini test etmek isteyebilirler. Çoklu örneklem ya da faktöriyel invaryans analizi olarak ta bilinen çoklu grup analizleri kullanılacaksa yapısal eşitlik modeli kullanılarak yapılacak bir doğrulama, yapısal invaryans veya eşit faktör yapılarının (faktör sayılarının ve faktör yüklerinin gruplar arasında özdeş olması gibi) varlığını gerektirmektedir. İkinci olarak, ilk seviye karşılaştırılabilirlik doğrulandığı takdirde araştırmacı alt boyutlar ve kısıt yapısının ortalamalarını doğrulamak üzere araştırmasına devam edebilir. Yapısal eşitlik modeli (YEM) açısından ele alındığında, bu tür bir doğrulama, metrik invaryansın ya da eşit faktör 
yüklerinin (örnek olarak; ölçeklerin, farklı katılımcı grupları için aynı ortalamalara ve yapıya sahip olup olmadığı) test edilmesini gerektirir. Üçüncü olarak, ölçek ortalamaları eşitse araştırmacılar ortalamalar arasında karşılaştırmalar yapma yolunu tercih edebilirler. Yapısal eşitlik modeli bakımından bu adım, göstergeler ve/veya gizli değişkenlerin ortalamalarının eşitliğinin (örnek olarak; farklı gruplardan insanların her kısıt için aynı değerleri vermesi) test edilmesini içerir (Brown 2006). İnanıyoruz ki bu ayrımlar kısıtların yapısal homojenliği konusunda ortaya çıkabilecek tartışmalara, kavramsal bir açıklık getirecektir.

\section{Hiyerarşik Boş Zaman Kısıtlar Modelinin Üç Önermesi}

Crawford vd. (1991) üç belirgin önerme varsaymaktadır: (a) boş zaman kısıtları birbirini takip eden hiyerarşik bir yapı içinde dizilmişlerdir (örnek olarak, bireyler; bireylerarası, içsel ve yapısal kısıtlarla ardışık bir yapı içinde karşılaşmakta ve değerlendirmektedirler), (b) bu dizi bir önem s1rasına göre var olmaktadır ( üç seviye en kuvvetli olan yakından, en uzakta olan şeklinde oluşmaktadır), (c) bu sinıflandırma aynı zamanda bir sosyal imtiyaz hiyerarşisine de işaret etmektedir (gelir, eğitim, cinsiyet, rrk vb. gibi sosyal sinıflar ve algılanan kisitlar arasındaki korelasyon sonucunda ortaya çıkan). Bu bölümde bu üç önermeden yola çıkarak oluşturulan hipotezlerin test edildiği ampirik çalışmaları gözden geçireceğiz.

\section{Ardışık Hiyerarşi: Ampirik Bulgular}

Boş zaman kısıtlarının ardışık bir hiyerarşik yapı sergilediğinden bahseden ilk önerme sık ve yoğun bir şekilde incelenmiştir. Meta modelleme ilkesini kullanan Raymore vd. (1993) ardışık hiyerarşi önermesini test etmek için istatistiksel prosedürler geliştirmiştir. Elde ettikleri sonuçlar önermenin varlığını destekleyen kanıtlar içermektedir. Geliştirdikleri prosedürler müteakip çalışmalarda tekrar edilmiştir (örnek olarak; Gilbert ve Hudson 2000; Hawkins vd. 1999; Walker vd. 2007) ancak raporlanan bulgular karışık sonuçlar içermektedir. Örnek olarak, Gilbert ve Hudson bireylerin kayak yapma tercihinde bulunmak için yapısal kısıtlarla karşılaşmadan önce içsel kısıtların üstesinden gelmeleri gerektiği sonucuna ulaşmışlardır ancak aynı zamanda tüm kayakçılar için bu tip kısıtın var olup olmadığ1 şüphesine neden olan, insanların içsel kısıtlarla yüzleşmelerinin de bir zorunluluk olmadığı ortaya çıkmıştır. Walker vd. ve Hawkins vd. aynı yöntemleri kullanarak tam aksi sonuçlara ulaşmışlardır. Walker vd. Kanada ve Çin'den iki grup üniversite öğrencisinin örneklemi oluşturduğu çalışmalarında hiyerarşik modeli destekleyen kanıtlara ulaşmışladır. Hawkins vd. ise zihinsel gelişim bozukluğu olan yetişkinlerden oluşan örnekleminde Raymond vd.'nin sonuçlarını tekrarlayamamışlardır.

Önerimiz bu tutarsız bulguların büyük ihtiyatla yorumlanmasıdır. Raymond vd. (1993) tarafından kullanılan prosedürün temelini oluşturan "daha az sayıdaki denek, hiyerarşi içindeki konumları yükseldikçe, ileri giderler" (s.109) varsayımının genelleştirilebilirliğini incelemek uygun olabilir. Raymond vd. ve Walker vd. (2007) tarafından yürütülen araştırmalar bağlamında doğru olsa da, bu varsayım, üzerinde çalışılan örneklemin karakteristik özelliklerine bağlı sebeplerden dolayı bazı durumlara uygulanamayabilir. Örnek vermek gerekirse, Gilbert ve Hudson (2000) tarafından Birleşik Krallık 'ta kayak kısıtları çalışmasında, katılımcılarının $\% 55$ 'i kayak konusunda önceden deneyim sahibi olduklarını belirtmişlerdir. Bu, Birleşik Krallık genel nüfusundaki aynı oranla karşılaştıııldığında (\%17'den az, Mintel 1996, Gilbert ve Hudson tarafından aktarılan) "dikkat çekici" (s.915) bir şekilde yüksektir. Katılımcıların büyük çoğunluğunun hâlihazırda içsel (hatta kişilerarası) kısıtları müzakere edip, kayak yapma için bir tercih oluşturduklarını, bu nedenle de Raymond vd. tarafından ortaya konan önermeyi desteklemeyen önceden var olan bir durumun ortaya çıktığından şüphelenmek mantıklı olacaktır.

Ampirik doğrulamaların yanı sıra, çok sayıda araştırmacı konu hakkındaki anlayışımızın pekişmesine yardımı olabilecek değerli bulgular sağlamaktadır. Yetişkin amatör buz patencilerin karşılaştıkları kısıtları ele aldıkları çalışmada McQuarterie ve Jackson (1996) "yapısal ve öncül kısıtları birbirinden ayırmanın problemli" (s. 475) olduğundan bahisle, eşzamanlı etkileşim modeli (Herderson ve Bialeschski 1993), Crawford vd. (1991) tarafından ortaya konan orijinal hiyerarşik modelinden türetilen geliştirilmiş bir modelin, buz patencilerin kisitlarla olan deneyimlerini lineer ve hiyerarşik modelden daha iyi açılayabileceğini 
önermektedirler. Benzer fikirler başka araştırmacılar tarafından da ileri sürülmektedir. Örnek olarak, geri besleme döngüleri formunda etkileşimler sergileyen üç kategoriden ibaret kısıtlar (Gilbert ve Hudson 2000), umulan (yapısal veya kişilerarası) kısıtların rasyonelleştirilmesi sonucunda ilginin azalması (Davies ve Prentice 1995'den aktaran Gilbert ve Hudson 2000; ayrica bkz. Jackson vd. 1993), algılanan erişilebilirlik problemlerinin (yapısal k1sitlar) tesislere yönelik tutumları etkilemesi (içsel kısıtlar, Scott ve Munson 1994), her kategori içinde hiyerarşik bir yapı (Nadirova ve Jackson 2000) ve döngüsel bir düzende meydana gelen kısitlar (Domingues 2003), verilebilir. Crawford vd. (1991) tarafından ortaya atılan ardışık hiyerarşi önermesinin katı bir biçimde yorumlanmasına karşı bir uyarı olarak algılanabilecek gözlenen bir örneğin, kalıc1 ve genelleştirilebilir bir model mi yoksa örneğe özgü yerel bir fenomen mi olduğunu söylerken ihtiyatlı olunmasını önermemize rağmen bütün bu fikirlerin boş zaman kısıtlarının artan bir biçimde kapsamlı ve sofistike olarak anlaşılabilmesi sürecine katkıda bulunduğuna inanıyoruz. Özellikle üzerinde durduğumuz nokta, kavramsal modelin hiyerarşik yapısına rağmen, gerçekte bir bireyin karşı karşıya kaldığı gerçekleşen kısıtların içsel kısıtlarla başlamak zorunda olmadığıdır. Bireyin karşılaşabileceği kısıtlar; duruşu, tutumları, ilgisi ya da katılım düzeyi, konu ile ilgili bilgi düzeyi ve becerisi, mekân ya da tesislere ulaşılabilirlik, sosyal ağ, kültürel geçmiş ve daha birçok unsur halinde karşımıza çıkabilir. Dahası, yukarıda belirtilen parametreler değiştikçe, kısıtlar da evrilmeye devam edeceklerdir.

Diğer taraftan, üç seviyedeki faktörler arası bir etkileşim olduğunu da kabul ediyoruz. Kısıtlarla ardışık bir biçimde karşılaşıldığı görüşünün aksi ispat edilmedikçe, bir kısıtın oluşumu, içselleştirme ya da müzakere süreci yoluyla akla gelebilecek herhangi bir seviye/alan kaynaklı bir faktör olabilir. Ancak, kısitların kendileri ve nedenleri arasındaki ayrım, kavramsal karmaşayı engellemek ve/veya aşırı geniş tanımlamaların önüne geçmek amacıyla, dikkatli bir biçimde yapılmalıdır. Bir örnek vermek gerekirse, yaşlı kadınların, sosyal olarak daha fazla onaylanan aktivitelere ayıracakları zamandan çalarak spor aktivitelerine katılmaları sonucu hissettikleri "suçluluk", boş zaman faaliyetinden alabilecekleri hazzı tam olarak yaşayamama- larına neden olmaktadır (Heuser 2005). Suçluluk duygusunu şekillendiren sosyal faktörlere rağmen (toplumun beklentileri gibi) bu kısıt tartışmasız bir biçimde içsel seviyede ortaya çıkmıştır, çünkü sosyal faktörlerin etkisi birey tarafından engelleyici unsurlar olarak algılanmadığı sürece fark edilmezler. Daha ileri giderek, araştırmacıların basit bir biçimde boş zaman kısıtlarını tanımlamanın ya da sinıflandırmanın ötesine geçerek daha zorlu bir süreç olan nasıl ortaya çıktıklarını (altlarında yatan sebepler gibi) anlamaya çalışmalarının daha yararlı olacağına inanıyoruz. Daha önce bahsi geçen alternatif argümanların, hiyerarşik boş zaman kısıtlar teorisini olumsuzlamak değil de mevcut modelin gelişimi için yön göstericiler olarak önem arz ettiğine inanıyoruz. Örnek vermek gerekirse; sonraki aşamalardan olan kısıtlarla nasıl karşı karşıya gelindiğini ele alan -müzakere ve motivasyon gibi ilgili süreçlerle ilgili -çok sayıdaki çalışmanın (Carrol ve Alexandris 1997; Jackson vd. 1993; Frederick ve Shaw 1995; Henderson vd. 1995; Hubbard ve Mannell 2001; Little 2002; Livengood ve Stodolska 2004; McQuarrie ve Jackson 2002; Oh 2005; Scott 1991; Scott ve Jackson 1996; Son vd. 2008) yanı s-ra her tip kısıtın öncüllerini araştırılması gibi. $\mathrm{Bu}$ bulgular, araştırmacılara bireylerin tecrübe ettikleri kısıtları şekillendiren kaynaklar ya da güçlerin (bunlar cinsiyete bağlı roller, akran beklentileri, kültürel normlar, ırk ayrımcıllğı, önyargılar, boş zamanların değerlendirilebileceği tesislerin yokluğu ya da sosyo-kültürel geçmişimizden kaynaklanan herhangi bir faktör olabilir) takibi konusunda yardımcı olurlar. Bu faktörlerin dikkate alınması demek, algıların yüzeysel olarak ölçümünden öteye geçerek, bu algıların ortaya çıkmasına katkıda bulunan geniş bir kişisel-sosyo-kültürel faktör ağının derinlerine inmek demektir (ayrıca bkz. Shaw ve Henderson 2005). Bazı kisitların kalıcı olabileceğine özellikle dikkat çekmek isteriz (örnek olarak, toplumun yapısına bağlı olarak boş zaman kaynaklarının mevcut olmaması ya da algilanan sosyal normların kişisel boş zaman faaliyetlerine katılım veya alınan haz üzerindeki olumsuz etkileri gibi, bkz. Iso-Ahola ve Mannell 2005). Bu tip bir kisitın etkileri çok derin ve geniş kapsamlıdır ve üstesinden gelinmesi ya da ortadan kaldırılması genellikle hem birey tarafında müzakere (örnek olarak, davranışın çeşitli yollarla değiştirilmesi, Henderson vd. 1995; Jackson ve Rucks 1995; Samdahl ve Jekubovich 1997) hem de toplum, kurumlar ya da diğer 
aracı kurumlar tarafında kolaylaştırma çabalarının varlığını gerektirir. Bu yönde çalışmaların halihazırda başlamış olduğunu görmekten memnuniyet duyuyoruz (Crawford ve Stodolska 2008).

\section{Önem Hiyerarşisi: Ampirik Bulgular}

Tekrar vurgulamak isteriz ki, hiyerarşi önermesi (potansiyel) boş zaman değerlendiricilerinin karşılaşabileceği her kısıtın yoğunluğu ya da gerçekte algılanan önemini harfiyen tarif eden bir reçete olarak yorumlanmamalıdır. Bunun yerine, her bir tür kısıtın, müzakere sürecindeki rolü ve boş zaman etkinliğine katılma/katılmama (örnek olarak; içsel kısıtlar en kuvvetli olanlardır çünkü onların üstesinden gelmeden boş zamanı değerlendirecek bir aktiviteye katılma isteği ya da tercihi ortaya çıkmaz, önceden var olan bir istekte de azalma veya yok olma görülür) kararının alınmasındaki önemini tartışmak istiyoruz.

Ancak, tüm bireylerin - tüm sosyal, kültürel ve tarihsel bağlamlarda- aynı tip kısıtları deneyimleyeceği ve aynı önemde ya da kuvvette algılayacağını beklemek naif bir davranış olurdu. Daha önce ifade edilen heterojenlik konusu insanların boş zaman kısıt algıları hakkındaki değişkenliği yeterince açık bir biçimde ortaya koymuştur. Jackson ve Scott (1999) tarafından belirtildiği gibi, boş zaman arayışının ne seviyede olduğundan bağımsız olarak (yeni bir aktiviteye başlamak, önceki bir aktivitedeki katılımı sonlandırmak, katılımın sıklığı, alınan hazzın kalitesi, ya da uzmanlaşma bakımından katılımın istenen bir düzeyde gerçekleşmesi gibi) bazı ortak temel kısıtların var olma eğilimine rağmen ifade ve boyutların göreli kuvvetleri ve önemleri kayda değer değişiklikler gösterir (Hultsman 1993; Jackson 1993; Jackson ve Dunn 1991; Jackson ve Rucks 1995; Searle ve Brayley 1992; Xiong 2007). Her bir tip kısıtın algılanan önemi, bireyin durumuna ve/veya özelliklerine bağlı olarak ta değişiklik gösterir. Mesela, Hawkins vd. (1999) zeka geriliği olan yetişkinlerde, içsel kısıtların öneminin toplumla yaşadıkları özgün ilişki ağları nedeniyle daha fazla olabileceğini öne sürmüşlerdir.

Yukarıdaki görüşlere bağlı olarak önermenin geçerliliği daha az muğlak bir konudur. İncelememiz, önermeyi destekleyen kanıtların varlığına işaret etmektedir. Alexandris ve meslektaşları, rekreasyonel spor faaliyetlerine bağlılık ve kısıtlar arası ilişkiyi araştırdıkları çalışmalarında, kişilerarası kısıtların, bağlılığın en kuvvetli belirleyicileri olduğunu bulmuşlardır (Alexandris vd. 2001). Kısıtların motivasyon üzerindeki etkisinin araştırıldığ1 bir çalışmada, kişilerarası kısıtların bireyin motivasyonu üzerinde olumsuz etkileri tespit edilmesine rağmen motivasyon ve diğer iki tip kısıt arasında bir ilişkiye rastlanamamıştır (Alexandris, Tsorbatzoudis ve Grouios 2002). Bu çalışmayla Crawford vd. (1991) tarafından ortaya konan hiyerarşik önem önermesi kısmi olarak desteklenmektedir. Samdahl ve Jekubovich (1997) hiyerarşik modeli, bireylerin gündelik hayatta karşılaştıkları kısıtları yorumlayabilmek için, gerçekleşmiş bir durumu açılayan (s.432) bir rehber (ex post facto) olarak kullanmışlar ve önem hiyerarşisi önermesini destekleyen doğrulayıcı kanıtlara ulaşmışlardır.

\section{Sosyal İmtiyaz Hiyerarşisi: Ampirik Bulgular}

Crawford vd. (1991) genellikle gelir ve eğitim tarafından şekillenen sosyal sınıfların, nihai olarak boş zaman faaliyetlerine katılımlarını etkileyen, kişilerin kısıtlar hakkındaki algıları ve deneyimleri üzerinde çok kuvvetli bir tesiri olduğunu tahmin etmektedirler. Her ne kadar bu önermeden, doğrudan ya da dolaylı bir biçimde var olan yayınlarda bahsedilmese de demografik değişkenler (cinsiyet, gelir, eğitim, etnik geçmiş gibi) ve algılanan kısıtlar (bkz. Jackson 2005) arası ilişkilerin ele alındığ çok çalışma ampirik kanıtlar içermektedir.

Sosyo-demografik değişkenler ve kısıtların yaygınlığı ve ölçeği arasında yakın ilişkiler olduğu kabul edilmektedir (Jackson ve Henderson 1995; Scott ve Munson 1994; Shaw ve Henderson 2005). Macarville ve Smale (1993) boş zaman aktivitelerine katılımı etkileyen, algılanan kısıtları beş ana alanda incelemişlerdir (fiziksel aktivite ve egzersiz, sanat ve eğlence, hobiler, sosyal aktiviteler ve evde eğlence). Elde edilen bulgular kısitların toplam popülasyon içinde dengeli bir dağılım göstermediğine işaret etmektedir. Düşük gelir grubuna dahil insanlar, varlıklı olanlara göre daha fazla kısıt rapor etmektedirler (algilanan yaş uygunluğu, sağlık, iletişim dili zorlukları, maliyetler, eşlik eden kişi olmaması, bilgi, erişilebilirlik/uygunluk). Alexandris ve Carrol (1997b) bireysel/psikolojik, ilgi/ negatif geçmiş tecrübeler, eşlik eden kişi olmaması, bilgi eksikliği, erişilebilirlik/finansal gibi algılanan kısıtların düşük eğitimli bireyler arasında daha yaygın olduğu sonucuna ulaşmışlardır. Elde edi- 
len bu bulgular Raymore vd. (1994) tarafından yapılan çalışmanın sonuçları ile uyum içerisindedir. Çalışmalarında sosyo-ekonomik statü (algılanan hane halkı geliri ve ebeveynlerin eğitim seviyeleri) ve algılanan kısıtlar arasındaki ilişkileri incelemişler ve sosyo-ekonomik statünün kişilerarası kısıtlar ile ters yönlü bir ilişki içinde olduğunu, yanı sıra diğer iki tip kısıt ve sosyo-ekonomik statü arasında dikkate değer bir ilişki bulunmadığı sonucuna ulaşmışlardır.

Özetlemek gerekirse, mevcut çalışmalarda kısıtların sosyo-ekonomik basamaklar içinde dağılımı, Crawford vd. (1991) tarafından yapılan spesifik tahminlere tam olarak uygun olmasa da kanitlar genel olarak boş zaman kısıtlarının tecrübe edilmesinde bir sosyal imtiyaz hiyerarşisinin varlığını destekler durumdadır. Dahası mevcut literatürden kaynaklanan ortak bir bulgu, kadınların, özelikle kişilerarası kısıtlar bakımından, erkeklere göre boş zaman konusunda daha fazla kısit tecrübe ettiğini göstermektedir (Culp 1998; Frederick ve Shaw 1995; Harrington 1991; Henderson 1991; Henderson ve Ainsworth 2000; Henderson vd. 1995; James 2000, literatür araştırması için bakınız Shaw ve Henderson 2005). Özünde cinsiyetle ilgili olan eşitlik meselelerinin de hiyerarşik sosyal imtiyaz önermesine dolaylı yoldan da olsa destek verdiğine inaniyoruz (Crawford vd. 1991).

\section{Teoriye Yönelik Eleştiriler}

Kisıtlar teorisi farklı yorumlamalara maruz kalmasına rağmen, biz kısıtların ilk kavramlaştırımının oldukça net olduğuna inanıyoruz. Aşağıda kısıtların kavramlaştırılmasına dair konulara ve bu konulara dair bakış açımıza yer verilmiştir.

\section{Hiyerarşik Boş Zaman Kısıtlar Modelleri Kültüre mi bağhldır?}

Bazı araştırmacılar kısıtların tipolojilerinin kültürü göz ardı ettiğini ve bu nedenle kültüre bağlı olduğunu savunmaktadırlar. Örneğin Chick ve Dong'a göre:

Crawford, Jackson ve Godbey tarafından geliştirilen hiyerarşik kısıtlar modeli görünüşe göre kısıtlar sınıflandırma sistemleri arasında kabul görmeye başlamıştır... Bu üç kısıt kategorisi bir antropoloğa göre çok bireysel odaklı algılanabilir... Üstelik bizler kültürün, sosyal bilimler düşününde dikkate değer bir geçmişi olan bir yapı olarak Crawford ve Godbey'in (1987) siniflama sis- teminden -kültürün bu sınıflandırmada diğer üç kategoriye göz ardı edilebilecek şekilde dağılmış olmasından dolayı-kolaylıkla ayrılabileceğine inanmaktayız. (s.170-171)

Bizler bu argümanı iki sebepten reddediyoruz. Kısaca açıklamak gerekirse ilki, gereksiz olması riskine rağmen, böyle bir iddiayı desteklemek deneye dayalı kanitlar (örn. deneysel yanlışlama) gerektirmektedir, ancak baktığımızda ilgili literatürde genelleştirilebilen, sistematik yanlışlama ortaya koyan çok az çalışmaya yer verildiğini görüyoruz. İkincisi, bireylerin içsel kısıtlar seviyeleri makro düzeyde farklılıkları kapsamaktadır. Örneğin, 1987'de biz şunları yazmıştık:

İçsel kısıtlar kişinin psikolojik durumunu ve yaklaşımlarını içerir, tercihlere ve katılımlara müdahale etmekten ziyade dinlence seçimlerine hitap etmeyi hedefler. Bazı içsel bariyerlere örnekler şu şekilde sıralanabilir: stres, depresyon, anksiyete, sofuluk, akraba ve akraba olmayan grup yaklaşımları, belirli dinlenme aktivitelerine dair önceden edinilmiş sosyalleşme, algılanan kişisel beceriler ve çeşitli serbest zaman aktivitelerinin uygunluğu ve mevcudiyetinin öznel değerlendirilmesi. (s.122)

Bütün bu örnekler ve buraya yazmadığımız dahası (bu tür kısıtların detaylı bir araştırmasını yapmaya çalışmadığımızı düşünürsek) ancak kültüre bağımlı düşünüldüğünde (örneğin, referans grup tutumları, sosyalleşme ve uygunluk algiları) bir anlam ifade etmektedir. İçsel kısıtlar daha önce bahsedildiği gibi temel olarak serbest zaman aktivitelerine bahsi geçen kişinin katılımın uygunluğuna ve ilintisine ilişkin öznel değerlendirmeleri ve algıları ile ilgilidir. Uygunluğa ve ilintiye dair verilecek kararın temelleri psikolojik, kültürel ve/ veya genetik yatkınlık olabilmektedir. Bu faktörler değişik ülkeler, dinler, kişilik, cinsiyetler, siyasi özgürlük, etnisite, psikolojik tutum ve bunun gibi diğer etmenler söz konusu olduğunda yoğunluk ya da öncelik bakımından farklılık gösterebilmektedir. Buradaki önemli soru söz konusu bireyin, söz konusu aktivitenin, uygun bir biçimde katılacağ tadını çıkarabileceği ve/veya başarıyı deneyimleyebileceği bir boş zaman aktivitesi olup olmadığı sonucuna varıp varamayacağıdır.

Kültürün her üç kısıt kategorilerine 'göze çarpmayacak şekilde yayılmış' olduğunu söylemektense, kültürün her üç kategorinin de temel açılay1C1 yapitaşı olduğunu ifade etmek daha doğru olacaktır. Örneğin, kişilerarası kısıtlar belli bir kültür içinde uygulanmalıdır. Bir toplumda din, insanla- 
rın katılacakları serbest zaman aktivitesini seçerken ağırlıklı rolü üstlenebilirken, başka bir toplumda hiçbir rolü olmayabilir. Bir kültürde 'tesis noksanlığı' yetişkin erkeklerin futbol oynamasına engel olurken, diğerinde sokakta oynayabilmektedirler. Bizim kısitlar kategorilerimiz ise bireysel düzeyde ortaya konulduğundan, ağırlıklı olarak kültür tarafından şekillendiği anlaşılmaktadır.

Chick ve Dong'un (2005) iddialarının bir kısmının nedeni de modeli eleştirirken kişisel kısıtların tam tanımı yerine bunu sadece 'kişisel kısıtlar' (örn. Stres ya da depresyon gibi psikolojik nedenler, "Hayatta yapmam" s.170) olarak ele almış olmalarıdır. Tanımın bu kısaltılmış hali 1987 tarihli makalemizde bahsedilen ve oldukça net ve ağırlıklı olarak kültürden etkilenen önemli örnekleri dışarıda tutmaktadır; akraba ve akraba olmayan grup referans tutumları, sofuluk, belirli serbest zaman aktivitelerine geliştirilen geçmiş sosyalleşme deneyimleri gibi. Chick ve Dong tarafından ortaya konulan şu görüşe saygı duymaktayız:

Bir antropoloğa göre bu üç kısıtlar kategorisi fazlasıyla birey merkezli olabilir. Her şeyden öte insan oldukça sosyal bir hayvandır ve sosyal çevremiz kişisel ve kişilerarası ilişkilerimizi yönlendiren hukuk, kural, norm ve bunun gibi - daha özellikle kültür- sistemlerinden oluşmaktadır (s170).

Kültürün kısıtları şekillendirdiğini söyleyerek sonlandırırken tanımlarımızın bu tür konuları da kapsadığ 1 inancındayız. Üstelik öyle ya da böyle gönüllü olarak içselleştirilmiş kültürel normlar ve dayatılmış kültürel normları ayırt edebilmekteyiz. Köktendinci Huristiyan inancına göre herkesin Pazar sabahı kiliseye gitmesi gerektiği gibi dayatılmış kültürel normlar yapısal bir kısıt oluşturabilmektedir. Yani, herhangi bir birey Pazar sabahı ormanda bir yürüyüşten keyif alabilecek ya da o sabah ormana yürüyüşe gitmek isteyen arkadaşlara sahipken kiliseye devamlılık gibi normatif bir mecburiyetle karşı karşıya kalabilir. Kişilerarası kısıtlar bakımından ele alındığında, kişi ormanda yürüyüşe gitmek isteyebilir ancak aynı kiliseye giden üyelere eşlik etmesi söz konusu olduğunda bu seçimi kısıtlanabilir. Bir şekilde gönüllü olarak içselleştirilmiş olan normlar genelde kişiye dönük kisttlar olarak karşımıza çıkabilir ve katılım isteğine yön verebilir. (örneğin: benim gibi insanlar Pazar sabahı ormanda yürümezler. Ben iyi bir Hıristiyan'ım ve kiliseye gitmek istiyorum. Bu yüzden, Pazar sabahı yürüyüşe gitmek istemiyorum)
Bireyler ve kültürler arasındaki ilişkiyi incelemek için Walker ve arkadaşları öz benlik kurgusunun etnik/1rksal serbest zaman araştırmalarına yeni bir ara değişken olarak dâhil edilmesini önerdiler. (Walker, Deng ve Dieser 2005). Eleştirmenlerimizden birinin de belirttiği üzere bu önermenin sosyal normların kişisel değerler ve inançlara dönüşmesi sürecine müdahil olması sonucunda kısıt algilar1nın artmasına yol açtığını kabul etmekteyiz. Kültürler arası kapsamda incelendiğinde, bu tarz araştırmalar kısıtlar ile ilintili psikolojik yapıların ne ölçüye kadar farklı işlediğini ve içsel, kişiler arası ve yapısal kısıtların yoğunluğunun kültüre göre nasıl farklılaşabildiğini ortaya koymaktadırlar. Aynı zamanda Walker ve arkadaşlarının (2008) çalışmasında bireysellik ve toplumsallık arasındaki farkların öz benlik kurgusunu tanımlamak için kullanıldığına dikkat çekmek istiyoruz ki bu, kurgunun incelenebileceği birçok boyut arasından sadece bir tanesidir. Serbest zaman yapılanmaları tartışılırken serbest zaman aktivitelerinin doğası ve özelliklerine bağlı olarak farklı kurallar ya da kişisel inançlar işin içine girmektedir (ayr. Bkz. Caldwell 2005). Söylenenlerin ışığında, bize göre öz benlik kurgusu tartışılabilir yeni bir değerdir. (Walker 2007; Walker vd. 2007; Walker vd. 2008). "Öz" kavramına dair oldukça geniş bir çerçeve mevcuttur - özgüven, öz değerlendirme, öz yeterlilik, bireysel imaj ve benzeri- ve bu bağlamda "benlik algısı" kavramını eşsiz olarak ifade etmek keyfi olarak görülmekte ve daha fazla kanıta ihtiyaç duyulmasına neden olmaktadır.

\section{Boş Zaman İle İlgili Tüm Kısıtları Kaldırmak Mümkün Müdür ve İstenen Bir Durum Mudur?}

Belirtmek isteriz ki bütün kısıtları ortadan kaldırmak mümkün değildir ve zaten istenen de bu değildir. Belirli bir serbest zaman aktivitesi için belirlenen içsel ve kişilerarası kısıtlar en aza indirildiğinde, katılım isteği artmakta; bunun sonucu olarak da kalabalık, sırada bekleme, maliyet gibi diğer yapısal sorunları çoğalacaktır. Kısıtlar mutlak olmadığına göre, kişiler sadece kendi istekleriyle bunların üstesinden gelebilirler mi? Biz bunun mümkün olmadığını düşünmekteyiz. Örneğin, kenar mahallelerden birinde yaşayan birisi daha önce koşuya çıkan birkaç kişinin saldırıya uğradığı bir yerde koşmak isteyebilir, böyle bir karar boşuna bir kahramanlık olurdu. Çoğu durumda kısıtlama- 
nın yoğunluğu o denli artar ki mutlak olmadığı bilinse bile kısıtlamaya boyun eğmek zorunda kalınabilinmektedir. "Hatırlatmakta fayda var ki kısıtlamalar boş zaman davranışlarımızın üstünde sadece etki yapabilirler, karar verici olamazlar ve serbest zaman davranışımızı belirleyen, tercihlerimize baktığımızda üstün gelen kısıtlamadır. (Crawford ve Godbey 1987: 124). Çan eğrisinin kenarlarında olduğu gibi, kısıtlar ağırlığını artırdıkça katılım ihtimali olumsuza doğru değişim gösterir.

Tahminlerimize göre, modelin geleneksel sosyal değişim teorisini kapsadığını görerek zamanla bu düzeylerin kısitlardan ziyade 'faktörler' ya da 'etkiler' olduğunu düşünmeye başladık. Bu analiz uygulandı ğında kısıtlar, etkileşim teorisinin 'bedeli' olarak yeniden yer bulabilir, ancak 'ödül' paralel konsepti, model içinde tam anlamıla yerini bulamamaktadır. Serbest zaman davranışlarını bedel ve ödülün etkileşimi olarak düşünmek mümkündür, karlılık da bunun içine katıldığında serbest zaman davranışı tanımının bir dizi aktivite içinden insanların zihinsel hesaplamalarıdır. Ne yazık ki bazen yapmaya değer bir aktiviteye dair tahminlerimiz boşa çıkabiliyor (örn. Her gün yağmur yağan bir yerde balığa çıkmak, film boyunca arkanızda oturan insanların sürekli konuştuğu bir sinemaya gitmek gibi). Thibaut ve Kelly'nin (1959) karşılıklı bağımlılık teorilerinin -daha sonra maalesef etkileşim teorisi olarak bilinmeye başladı- temellerinde sıradan bir aktiviteye katılımda kişilerarası koordinasyonun gerekli olduğunun önemini vurgulamaktadır. Bu, kişisel tercihlerin karmaşık doğasını ve peş peşe katılımın gerçekleştiği serbest zaman aktivitelerini eşit zeminlere indiren, modeldeki kişilerarası düzeyde oluşan enerjiydi.

Bizler özgür irade/önyargının hala yürürlükte olduğunun ve bir eylemin zaman içinde herhangi bir noktasında birden çok kısıtlamanın olabileceğinin farkındayız. Örneğin, içsel düzeyde, basketbol oynamayı çok sevmeme rağmen bu akşam oynayamayacak kadar yorgun olabilirim. Başka bir örnekte; eşleriyle hoşlanmadıkları halde paylaştıkları ancak erkeğin hoşuna giden boş zaman faaliyetleri mutsuz evliliklerin kuvvetli bir öncülü olarak karşımıza çıkmaktadır (Crawford, Houts, Huston ve George 2002). Bu örnekte, kadının aktivitede (örn. tenis) yer almaktaki isteksizliği eşiyle birlikte bir aktivitede yer alma isteğiyle karşılaşabilir (ve evlilikte güç dengesinde radikal asimetriye kadar gi- debilir). Bu durumda, kadının, eşiyle bir aktivitede yer almak ( kişilerarası etken) isteği (ya da belki zorunluluk) adına tenise karşı geliştirdiği kişisel tercihlerini bir kenara bırakır. Tam tersi düşünüldüğünde, kadın tenis oynamaktan keyif alabilir ancak bundan önceki birkaç tenis maçında çift tartıştıysa, oyuna katılmak istemeyebilir ki bu da başka bir kişilerarası engel olarak karşımıza çıkar. Bu nedenle, çok faktörlü çözümler normlar olacaktır ve biz her zaman bu üç düzeyi etkilerin (çok faktörlü bir şekilde) kümesi (genellikle dengeleyici) olarak görmekteyiz.

\section{Hiyerarşik Boş Zaman Kısıtlamaları İçsel Kısıtlamalarla mı 'Başlar'?}

Esasen, model döngüsel olduğundan başlama noktası kişinin ya da grubun günlük yaşamları içinde nerede olduğudur. Squash oynamayı çok seven ancak squash sahalarının bulunmadığ 1 küçük bir kasabaya taşınan birinden başlarsak, kortların olmayışı yapısal bir kısıtlama teşkil etse de, zaman içinde bu durumu kişi için içsel bir engel haline getirecektir, tıpkı Ezop'un tilki ve üzüm hikâyesinde ${ }^{2}$ olduğu gibi. Yani, bir noktadan sonra squash oynamak için fırsat aramaktan vazgeçecektir. Ayrıca, imkânlar el verdiği takdirde raketbol ${ }^{3}$ ya da başka bir raket sporuna ilgi duyabilecektir. Grup söz konusu olduğunda, eğer kadınların squash oynamak için gerekli olan koşmasını engelleyen geleneksel kıyafetler giymeleri gerekiyorsa, yine kıyafetin rahatlığ 1 konusu katılım isteğini içsel bir engele dönüştürebilir. Bu durumda, oynanabilecek uygun kortlar ve kişiler olduğunda, bu kadınlar squash oynayabileceklerdir.

\section{Hiyerarşik Boş zaman Kısıtlar Teorisinin Disiplin içi ve Disiplinlerarası İlişkisi}

Hiyerarşik Boş Zaman Kısıtlar Teorisi Tüm Serbest zaman Davranışlarına Uygulamayı mı amaçlamaktadır?

Çiftler arasındaki katılım konusunu bu kadar vurguladıktan sonra çiftlerden birinin ya da her ikisinin bir tür uzlaşmaya vardığını görmekteyiz. Samdahl ve Jekubovisch'e (1997) göre: "Eğlence

\footnotetext{
${ }^{2}$ Çevirenin notu: Ezop hikayesinde tilki, girdiği asma bahçesinde yüksekte asılı duran üzümlere erişemeyeceğini anlayınca "nasılsa olgunlaşmamışlardı" diye özetlenebilecek kendince bir bahane üretir.

${ }^{3}$ Çevirenin notu: Squash ve hentbol karışımı bir tür oyun.
} 
kısıtlamaları asla tüm serbest zaman davranışını belirleyecek evrensel bir çerçeve çizmek niyetinde olmamıştır, bu yüzden bir noktaya kadar eleştirilerimiz haksız olacaktır."(s.447). Aslında, itiraf etmek gerekirse modelimizin tüm serbest zaman katılımına ya da katılınmamasına evrensel bir açıklama getirmesini hedefledik. Bilginin başka birçok türü elbette gereklidir. Samdahl ve Jekubovich'in doğru bir biçimde gözlemlediği gibi katılımın, tamamı ile özgür irade, önyargının sonu, sosyal adalet sağlanması ve hatta eğlenmek anlamına gelmediğini görmeli ve dikkatli olmalıyız. Ancak 21 yıl önce tahmin etmek ve açıklamak amacıyla kurulan modelin ortaya koyduğu gibi bir boş zaman aktivitesinde katılımın gerçekleştiği ve bunun bir davranış olduğu - özgür irade, adaletsizlik veya haz olmadı ̆̆ı- anlamına gelmektedir. Başka bir deyişle, modelin nihai hedefi fiili davranışı tahmin etmektir. Boş zaman aktivitesine katılımın öncüllerini anlamamıza yardım etmesi için muhtelif zihinsel ve sosyal fenomenler farklı boyutlarda incelenmiştir.

Yinelemek gerekirse, kişilerarası uzlaşma olgusu - eş, arkadaş, kardeş, aile ya da çocuklar arasında olması fark etmez- kişiler arası modele verdiğimiz önemin altını çizmektedir. Evlilik sorunları üzerinde çalışan biri uzlaşmanın iki ucu keskin bıçak olduğunun farkına varacaktır; çiftler ikisinin de istediği bir aktiviteye çift olarak katılmak isteyebilirler, ya da hiçbirinin aslında katılmayı istemediği ve sonunda katılmaktan vazgeçtikleri bir durumla da karşılaşabilirler. Bu tür çıkar çatışmaları aynı zamanda Kelley'nin (1979) karşılıklı bağımlılık eserinin temelini oluşturmaktadır, çünkü kişiler arası uyum talebi bu durumlarda en üst düzeye çıkmaktadır. Kelley'in merkezi gelişim modeli ve kişiler arası faktörlerdeki fikirleri bize göre 1987'de aktardığımız kadarından çok daha fazlaydı, yine Kelley'nin (1979) gözleminde belirttiği gibi:

\footnotetext{
Sonucun hem her bir kişi tarafından hem de çift tarafından birlikte kontrol ediliyor olması sonucun karşılıklı bağımlılık yapısının en temel özelliğini ortaya koyarken yakın ilişkileri karakterize etmektedir. Bu şu demektir ki çift sadece etkileşim sorunu ile değil diğeri için bir şey yapma ve -eşit derecede önemli olan- müdahale etmeden diğerini yönetme, birlikte ortak aktivitelerde 'uyum' sorunuyla karşı karşıya kalırlar. (s.23).
}

Başka bir deyişle, çift birinin sevdiği ama diğerinin hoşlanmadığ 1 bir aktivitede yer almazsa (Bkz. Crawford vd. 2002. account of the effects of such leisure on wives' marital satisfaction) - ya da kendi sev- dikleri aktivitelere ayrı ayrı katılmazlarsa- uzlaşma gerekli hale gelmektedir. Ne yazık ki, eleştirmenlerimizden birinin de belirttiği gibi kişilerarası ve bunun gibi birçok kısıtlama türünün var olmasına rağmen, çok az araştırmacı kısıtlar teorisini detaylı bir şekilde bu düzeyde incelemiştir. Kısıtlama araştırma sürecine dâhil edilen sosyo-psikolojik süreçler ve uzlaşma davranışında görülen bedeller daha sonraki çalışmalarda etraflıca incelenecektir.

\section{Hiyerarşik Boş Zaman Kısıtlar Teorisi Sadece Serbest Zaman Davranışına mı uygulanabilir?}

Teori göründüğü kadarıyla çeşitli insan davranışlarına uygulanabilir görünmektedir. Örneğin, mesleki tercihler konusunda anlayış kazandırmak üzere kullanılabilir. Örneğin bir genç bir erkek hemşire olmak isteyebilir ve kişisel olarak hemşire eğitimi 'uygunluk ve mevcudiyet öz değerlendirmesi' tarafından kisitlanabilir (Crawford ve Godbey 1987: 122). Öz değerlendirmenin olumsuzlukları aşıldığında bu kez bu eyleme beraber katılacağı kişiler ve onların uygunlukları sorunları gündeme gelecektir. Bu engel de aşıldığında belki hemşire olmak isteyen başka erkekler bulmak ya da bu isteğine sempati duyan kadınlar bulma sorunu aşıldığında son engeller ulaşım ve öğrenim ücretleri gibi yapısal olacaktır.

Bu nokta aynı zamanda George Herbert Mead'in tam olmasa da retorik sorusuna varmaktadır: toplum nasıl kişinin 'içine girebiliyor', sosyal normlarl, beklenen davranışları nasıl öğreniyoruz? Zaman içinde yapısal/kültürel kısıtlamalar makro düzeyde içselleştirilmiş ve tarafımızdan sosyal olarak koşullandığında kendi ‘seçimimizmiş' gibi görülmeye başlamıştır (olumlu ya da olumsuz yaptırım olduğuna bakılmaksızın). Bu nedenle model serbest zamanın ötesinde birçok aktivite türüne dair sosyalleşmeyi ya da ondan uzaklaşmayı konu alan sorulara dair yaklaşım sunmuştur.

\section{Boş Zaman Kısıtı Kavramı Çok Mu Genel?}

Mannell ve Loucks-Atkinson (2005) araştırmac1lar arasında boş zaman kısıtları teriminin 'rahatça' kullanılmaması konusunda uyarıda bulunmuşlardır (örneğin katılımı etkileyen her bir faktörün kısıtlama olarak adlandırılması gibi s.229). Bu sonuçlara biz de katılıyoruz ve özellikle vurgulamak istediğimiz nokta, boş zaman tercihlerinin oluş- 
masına engel olan faktörlerin, içsel kısıtlar olarak kavramsallaştırılmasının öneminin farkında olmamıza rağmen bu kavram araştırmacıların kolaylıkla geoşeyebildikleri bir durumdadır. Konuyu açıklık getirmek adına, 'ilgi azlığı' ifadesinin sıklıkla içsel bir kısıtlama olarak adlandırıldığını belirtmeliyiz. Araştırmacılar olarak bizler insanların belli serbest zaman aktivitelerinde karşılaştıkları kısıtlamaları ele almak üzere yola çıktığımızdan, kayak örneği mesela, az ilgi gösteren bir kişiyi içsel olarak kısıtlanmış olarak adlandırmaktayız. Kişi snowboard'a ilgi duyuyorsa ne olur? Peki ya kişiye farklı araştırmacı grupları tarafından farklı araştırmaların konusu olarak ilgi alanının tamamen dışında belirli aktiviteler konusunda sorular sorulduysa? Tüm araştırmacılar tarafından içsel olarak kısıtlanmış olarak adlandırılmasına rağmen, bu kişi son derece sağlıklı ve kendi serbest zamanını mutlu bir şekilde geçiriyor olabilir, tek sorun onun aktivitelerinin araştırmacının listesinde bulunmamasıdır. Asıl mesele her birimizin sadece sinırlı sayıda serbest zaman aktivitesine sahip olmamızdır. Bir aktiviteye ilgi duyduğumuzda diğerine olan ilgimiz azalabilir ya da tamamen kaybolabilir. Araştırmacılar ikincisini "kısıtlama" olarak adlandırırken dikkatli olmalıdır, Walker ve Virden (2005) bu konuyu aydınlatacaklardır " motivasyon insanın eğlence performansını belli bir noktaya yönlendirdiğinden, diğer yönleri kısıtlayabilmekte veya sinırlayabilmektedir" (s. 203). Tercih listemizde olmayan şeyleri kısitlamanın bir sonucu olarak görmek doğru mudur? Cevap evetse, kısıtlamanın bu denli geniş olan tanımı nasıl işimize yarayabilir? Kendi içinde hiçbir tercihi bulunmayan kapsamlı bir listeye sahip olmak mümkün ve istenen durum mudur?

Bununla birlikte, peki ya kişinin inanç ve tutumları doğrultusunda bir ilgi azlığından söz etmek gerekirse? Örneğin, avcilıkla ilgili bir araştırmalarında Wright ve Goodale (1991) son derece ilgisiz, katılımcı olmayan ve avcılıkla ilgili çok güçlü karşıt inançlara ("'av yasaklanmalı, çünkü artık hayatta kalmak için avlanmaya gerek kalmadı", "avlanmak savunmasız hayvanları öldürür ve yasaklanmalıdır", "avlanmak ahlaka aykırıdır" gibi) sahip, avlanmak dışında başka aktiviteler yapma konusunda net tercihleri olan bir gruba rastlamıştır (s.324). Bütün bu ilgisiz, katılımda bulunmayanları içsel olarak kısıtlanmış olarak nitelendirebilir miyiz? Bu noktada değer yargılarının işin içine girdi- ği görülebiliyor. Burada tartışmamızın anlaşılırlığı açısından kabul etmemiz gereken serbest zaman kısitları, Mannell ve Loucks-Atkinson'ın deyimiyle (2005) insanların onlar için 'iyi olan' şeyleri yapmalarını engelleyen faktörlerdir. Çoğu zaman 'neyin iyi" olduğu konusunda çok az muğlaklık bulunmaktadır. Buradaki ayrım, özellikle kültürler arası çalışmalarda çok hassas olabilir (örn. Walker vd. 2007, Walker vd. 2008). Başka bir kültürden bakıldığında 'iyi' ya da 'sağlıklı' olarak görülen bir aktivite kişileri kültürel değerleri doğrultusunda bu aktiviteye katılmaktan alıkoyabilir, böyle bir durumda inançları hareketlerini kısıtladığından bu 'engellemeler' konusunda kişi eğitilmeli ya da ikna edilmeli midir? ${ }^{4}$ Kültürel farklılıklarla ilgili bu soru aynı zamanda kişisel farklılıklarla da ilgilidir. Ya insanın karakteri önümüze çıkıyorsa? (Mannell ve Loucks-Atkinson). Birey karakterinden mi kurtulmalı? Ve bunu yapmak mümkün müdür?

Şunu belirtmekte fayda var ki araştırmamız ayrım yapmaksızın var olan bütün değer/inançları ya da bireysel farklılıkları kapsayan bir söylem değildir. Bundan ziyade, kadınlar için sosyal gerçeklerce dayatılan eşitsizliklerden kaynaklanan eğlence k1sıtlayıcı tutum/inançları (örn. yetkilendirme eksikliği) tanımlayan feminist çalışmaların katkısının da farkındayız. Söylemeye çalıştı̆̆ımız şey, 'kısıtlama' etiketini kullanırken daha dikkatli olmak gerektiği ve tercih oluşumunda ve/veya katılım aşamasında etkili olan tüm faktörleri 'kısıtlayıcılar" olarak tanımlama hatasına düşmemek gerektiğidir. Bu soruna basit bir çözümün olmadığını biliyoruz, ancak en azından araştırma konularının sosyal-tarihi boyutlarıyla ele aldığımız iyi ve sağlıklı boş zaman ile ne anlatmak istediğimizi açı bir şekilde ortaya koyarak başlayabiliriz

\section{Gelecek Araştırmalar için Öneriler}

Var olan boş zaman kısıtları öğelerini ele aldığımızda, ileriki araştırmalar için yapılması gereken en önemli şeyin ölçek geliştirme olduğuna inanıyoruz (kısıt faktörü havuzu oluşturarak, kısıtın ikinci sırada gelen yapısını araştırmak gibi). Böyle bir araştırma meselenin özünü daha net kavramamı-

\footnotetext{
${ }^{4}$ Bunun yanı sıra, bir hakemin öngördüğü gibi "bir aktivitenin diğerinden daha iyi veya sağlıklı olacağına kim karar verebilir? Kendi değerlerini başkalarına dayatanlar mı?" Buna benzer soruların kültürler arası araştırmalar için oldukça değerli olduğuna inaniyoruz.
} 
za yardımcı olacaktır. Bu, sadece değişik alt alanlardan gelmiş araştırmacıların aynı ölçeğe yatırım yapmasının tekrarına önüne geçmekle kalmayacak, aynı zamanda farklı ortamlarda aynı kısıtlamaları hedef alan çalışmalarda bir noktaya kadar ölçekte standartlık sağlayacaktır ki bu da çalışmalar arası referans, karşılaştırma ve bilgi birikimini kolaylaştıracaktır. Diğer bir nokta, kısıtlamaların oluşumuna katkı sağlayan faktörlerin geçmişini inceleyen birçok araştırma sistematik araştırmalar için-her ne kadar bazıları bunu dolaylı olarak yapmışsa da- temel bir birikim oluşturmaktadır. Bu tür bir araştırma sonuç itibarı ile boş zaman davranışını kısıtlayan engelleri ortaya çıarabilmekte ve azaltılması ya da ortadan kalkması için müdahale programları hazırlamaya yardımcı olabilmektedir.

Bütünleyici başka bir araştırma için bir diğer yön de ilgili parametrelerin (demografik/kültürel geçmiş, aktivitenin türü, katılım düzeyi ve bunun gibi) kısıtlama algısını şekillendirmede, kısıtlama ve bununla ilgili ilişkilendirme süreçlerinin moderatörü olarak etkilerini inceleyerek heterojenliğin haritasını çıkarmak olacaktır. Yukarıda bahsedilen bütün faktörleri incelemek için gereken deneysel çaba oldukça zahmetlidir ve araştırmacılar tek bir faktöre odaklanmak ve onun etkileri konusunda sistematik araştırmalar yürütmek durumunda kalabilmektedirler. Örneğin, kısıtlama ile ilgili çalışmaları yaşam süreci konularına bağlayan araştırmaları bir düşünün. Tercih oluşumunu - kariyer ile ilgili tercihlerin oluşması gibi serbest zaman ile ilgili olanlar gibi (Schuienberg 1984)- konu alan birçok araştırma ergenlik ve ilk çocukluk yıllarına odaklanır çünkü bu yaşlarda bu tür tercihlerin oluşmaya başladığına inanılır. Benzer şekilde, alanın bu anlamda yaşamın diğer ucuyla (emeklilik ve sonrası) ilgili de faydalı bilgiler sağlayacağını savunmaktayız. Burada model şunu da öngörmektedir ki norma benzer kısıtlamalar kişinin olgunlaşma/yaşlanma ile ilişkilendirilen fiziksel yeteneklerde değişiklik, sağlık engelleri, serbest zaman aktivitesinde istikrarsızlık gibi kişisel kısıtlamalarını da etkilemektedir.

Örneğin, Festinger'in (1957) 'doğruluk' ya da 'mantık' ilkesinde önerdiği gibi insanlar yapamadıklarını düşündükleri bu tür etkinliklerden uzak dururlar. Bunu dışında, tahminler kısıtlama düzeylerine yayılabilir, aktiviteye beraber gidilen kişinin olmayışı (yine burada kişiler arası düzeyde içsel kısıtlamayı görmekteyiz) azalan gelir ve imkânlara ulaşım kadar (yapısal kısıtlamalar) etkilidir. Aynı doğrultuda, serbest zaman kısıtlamaları ve davranışları arasındaki karşılıklı oyunların detaylı anlaşılması için şunlara gereksinim duyarız; zamanla kısıtlamaların kendi içinde ve bireylerin, grupların onları algılama biçimlerindeki değişiklikler ile ilgili soruları boylamasina sormaya ve cevaplamaya başlamalıyız. Başka bir deyişle, sosyal ve tarihsel zamanlar arası değişimlerle - sosyal/kültürel yapıdaki yeni değerlendirmeler sonucunda cinsiyet rolünde, değerlerde, kadının modern serbest zamanını geçirmesine bağlı artan fırsatlar gibi- ilgilenen eş zamanlı araştırmalar, bireysel zaman içinde serbest zaman kısıtlamaları deneyimlerinin önemini vurgulayan yaşam süreci çalışmalarıyla beraber yürümektedir. Bu tür birey- ve kültürler arası ilişkileri belirleyen istatistikî araçlara ulaşmanın mümkün olduğunu (hiyerarşik lineer modelleme, gelişim ça$\mathrm{n} ı$ analizi vb.) mutlaka burada belirtmeliyiz.

\section{SONUÇ}

Bu çalışmada kısıtlar teorisinin mevcut durumuna dair düşüncelerimizi sunduk ve burada bahsedemediğimiz birçok konunun olmasının yanı sıra özellikle önemli olduğunu düşündüğümüz ileriki araştırmalara yol gösterecek önerilerimizi belirttik. Savunduğumuz aslında oldukça basit: kendi fikrimiz. Teorinin kavramsal eleştirilerini anliyor ve sistematik deneysel boşa çıkarmaları bekliyoruz. Bu konuda incelenen deneysel çalışmalar bizi k1sitlar teorisini destekleyen genel kavramların geçerli olduğuna ve analiz çerçevesinin düzeyleri ile serbest zamanı içeren ama bunun da ötesine giden davranışsal seçimleri konu alan karar verme süreci ile tutarlı olduğuna inandırdı. Bu nedenle, teorinin temel prensiplerinin - bireysel, kişilerarası ve yapısal kısıtların yapısı- uygun ve faydalı olduğunu bilmemize rağmen şu konulardaki ileriki araştırmaları görmek için sabırsızlanıyoruz: (a) bu öğelerin öneminin tekrar vurgulanması; (b)ilgili olabilecekleri başka yöntemler önermeleri ve (c) onları temsil eden ölçülebilir değişkenleri ortaya çıkarmalarıdır. Bilim tarihine bakıldığında, teorilerin onları test etmek için kullanılan metotlardan çok daha önce var olduğunu görmekteyiz. Neyse ki, bu, boş zaman kısıtlamalarının sonucu ve geçmişi ile ilgili bir durum değildir ve ampirik çalışmalar alanımızdaki bilimselliğe katkıda bulunacak niteliktedir. 


\section{KAYNAKÇA}

Alexandris, K. ve Carroll, B. (1997a). An Analysis of Leisure Constraints Based on Different Recreational Sport Participation Levels: Results from a Study in Greece, Leisure Sciences, 19: 1-15.

Alexandris, K. ve Carroll, B. (1997b). Demographic Differences in the Perception of Con-straints on Recreational Sport Participation: Results from a Study in Greece, Leisure Studies, 16 (2): 107-125.

Alexandris, K., Grouios, G., Tsorbatzoudis, H. ve Bliatsou, P. (2001). Relationship be $\neg$ tween Perceived Constraints and Commitment to Recreational Sport Participation of University Students in Greece, International Journal of Sport Management, 2: 282-ᄀ297.

Alexandris, K., Tsorbatzoudis, C. ve Grouios, G. (2002). Perceived Constraints on Rec-reational Sport Participation: Investigating Their Relationship with Intrinsic Motiาvation, Extrinsic Motivation and Amotivation, Journal of Leisure Research, 34 (3): 233-252.

Arab-Moghaddam, N., Henderson K. A. ve Sheikholeslami, R. (2007). Women's Leisure and Constraints to Participation: Iranian Perspectives, Journal of Leisure Research, 39 (1): 109-126.

Auster, C. J. (2001). Transcending Potential Antecedent Leisure Constraints: The Case of Women Motorcycle Operators, Journal of Leisure Research, 33 (3): 272-298.

Backman, S. (1991). An Investigation of the Relationship between Activity Loyalty and Perceived Constraints, Journal of Leisure Research, 23: 332-344.

Backman, S. J. ve Crompton, J. L. (1989). Discriminating Between Continuers and Discontinuers of Two Public Leisure Services, Journal of Park and Recreation Administration, 7: 56-71.

Backman, S. J. ve Crompton, J. L. (1990). Differentiating Between Active and Passive Discontinuers of Two Leisure Activities, Journal of Leisure Research, 22: 197-212.

Berger, P. ve Luckmann, T. (1966). The Social Construction of Reality: A Treatise in the Sociology of Knowledge. Garden City, NY: Doubleday \& Company.

Brown, T. A. (2006). Confirmatory Factor Analysis for Applied Research. New York, NY: Guiford Press.

Brown, P. R., Brown, Y. M. ve Hansen, V. (2001). Perceived Constraints and Social Support for Active Leisure among Mothers with Your Children, Leisure Sciences, 23: 131-144.

Burns, R. C. ve Graefe, A. R. (2007). Constraints to Outdoor Recreation: Exploring the Effects of Disabilities on Perceptions and Participation, Journal of Leisure Research, 39 (1): 156-181.

Caldwell, L. L. (2005). Self-Construal in Context: A Response to Walker, Deng, and Dieser, Journal of Leisure Research, 37: 106-116.

Carroll, B. ve Alexandris, K. (1997). Perception of Constraints and Strength of Motivantion: Their Relation to Recreational Sport Participation, Journal of Leisure Research, 29: 279-299.

Chick, G. ve Dong, E. (2005). Cultural Constraints on Leisure. E. J. Jackson (Ed.), Constraints to leisure (ss. 169-185). State College, PA: Venture. the Isomorphism of the Hierาarchical Leisure Constraint Typology. (Yayımlanmamış Doktora Tezi). Clemson University. (Yayın no. AAT 3071548).

Crawford, D. W. ve Godbey, G. (1987). Reconceptualizing Barriers to Family Leisure, Leisure Sciences, 9: 119-127.

Crawford, D. W., Jackson, E. L. ve Godbey, G. (1991). A Hierarchical Model of Leisure Constraints, Leisure Sciences, 13: 309-320.

Crawford, D. W., Houts, R. M., Huston, T. L. ve George, L. J. (2002). Compatibility, Leisure, and Satisfaction in Marital Relationships, Journal of Marriage and the Family, 64: 433-449.

Crawford, J. L. ve Stodolska, M. (2008). Constraints Experienced By Elite Athletes with Disabilities in Kenya, With Implications for the Development of a New Hierarchical Model of Constraints at the Societal Level, Journal of Leisure Research, 40 (1): 128ᄀ-155.

Culp, R. H. (1998). Adolescent Girls and Outdoor Recreation: A Case Study Examining Constraints and Effective Programming, Journal of Leisure Research, 30 (3): 356-379.

Dominguez, L. A. (2003). Constraints and Constraint Negotiation by Women Sea Kayakers Participating in a WomenOnly Course. Doktora tezi. Michigan State University. (Yayin No. AAT 3100416).

Dunlop, P. M. (2006). Active Employees! Exploring the Relationship between Job Characteris $\neg$ tics, Perceived Constraints and Participation in Leisure-Time Physical Activity. (Yayımlanmamış Doktora Tezi). The University of North Carolina at Chapel Hill. (Yayın No. AAT 1432756).

Elkins, D. J. (2004). Levels of Perceived Constraint: A Comparative Analysis of Negotiation Strategies in Campus Recreational Sports. (Yayımlanmamış Doktora Tezi). Indiana University. (Yayın No. AAT 3152800).

Festinger, L. (1957). A Theory of Cognitive Dissonance. Stanford, CA: Stanford University Press.

Frederick, C. J. ve Shaw, S. M. (1995). Body Image as a Leisure Constraint: Examining the Experience of Aerobic Classes for Young Women, Leisure Sciences, 17: 57-53.

Gilbert, D. ve Hudson, S. (2000). Tourism Demand Constraints: A Skiing Participation, Annals of Tourism Research, 27: 906-925.

Han, W. (2004). Leisure Participation and Constraints: The Case of Korean Americans. (Yayımlanmamış Doktora Tezi). The Pennsylvania State University. (Yayın No. AAT 3147618).

Harrington, M. A. (1991). Time after Work: Constraints on the Leisure of Working Women, Loisir et Société, 14 (1): 115-132.

Hawkins, B. A., Peng, J., Hsieh, C. M. ve Eklund, S. J. (1999). Leisure Constraints: A Replication and Extension of Construct Development, Leisure Sciences, 21 (3): 179--192.

Henderson, K. A. (1991). The Contribution of Feminism to an Understanding of Leisure Constraints, Journal of Leisure Research, 23 (4): 363-377.

Henderson, K. A. ve Ainsworth, B. E. (2000). Enablers and Constraints to Walking for Older African American and American Indian Women: The Cultural Activity Participation Study, Research Quarterly for Exercise and Sport, 71 (4): 313-321.

Henderson, R. A. ve Bialeschki, M. D. (1993). Exploring an Expanded Model of Women's Leisure Constraints, Journal of Applied Recreation Research, 18: 229-252.

Henderson, K. A., Bedini, L. A., Hecht, L. ve Shuler, R. (1995). Women with Physical Disabilities and the Negotiation of Leisure Constraints, Leisure Studies, 14: 17-31. 
20 Yıl Sonrasında Hiyerarşik Boş Zaman Kısıtlar Teorisini Değerlendirmek Heuser, L. (2005). "We're Not Too Old to Play Sports": The Career of Women Lawn Bowlers, Leisure Studies, 24: 45-60.

Hubbard, J. ve Mannell, R. (2001). Testing Competing Models of the Leisure Constraint Negotiation Process in a Corporate Employee Recreation Setting, Leisure Sciences, 23 (3): 145-163.

Hultsman, W. Z. (1993). Is Constrained Leisure an Internally Homogeneous Concept? An Extension, Journal of Leisure Research, 25: 319-334.

Hultsman, W. Z. (1995). Recognizing Patterns of Constraints: An Extension of the Exploration of Dimensionality, Journal of Leisure Research, 27 (3): 228-244.

Iso-Ahola, S. ve Mannell, R. (1985). Social and Psychological Constraints on Leisure. M. G. Wade (Ed.), Constraints on leisure (ss. 111-151). Springfield, IL: C. C. Thomas.

Jackson, E. L. (1993). Recognizing Patterns of Leisure Constraints: Results from Alternative Analyses, Journal of Leisure Research, 25: 129-149.

Jackson, E. L. (1994). Activity-Specific Constraints on Leisure, Journal of Park and Recreation Administration, 12 (2): 33-49.

Jackson, E. L. (1997). In the Eye of The Beholder: A Comment on Samdahl ve Jekubovich (1997), "A Critique of Leisure Constraints: Comparative Analyses and Understandings." , Journal of Leisure Research, 29: 458-468.

Jackson, E. L. (2005). Leisure Constraints Research: Overview of a Developing Theme in Leisure Studies. E. L. Jackson, (Ed.), Constraints to leisure (ss. 3-19). State College, PA: Venture.

Jackson, E. L. ve Dunn, E. (1991). Is Constrained Leisure an Internally Homogeneous Concept?, Leisure Sciences, 13: 167-184.

Jackson, E. ve Henderson, K. (1995). Gender-Based Analysis of Leisure Constraints, Leisure Sciences, 17: 31-51.

Jackson, E. L. ve Rucks, V. C. (1995). Reasons for Ceasing Participation and Barriers to Participation: Further Examination of Constrained Leisure as an Internally Homoge $\neg$ neous Concept, Leisure Sciences, 15: 217-230.

Jackson, E. L. ve Scott, D. (1999). Constraints to Leisure. E. L. Jackson ve T. L. Burton (Ed.), Leisure studies: Prospects for The Twenty-First Century (ss.299-321). State College, PA: Venture Publishing, Inc.

James, K. (2000). "You Can Feel Them Looking At You": The Experiences of Adolescent Girls at Swimming Pools, Journal of Leisure Research, 32: 262-280.

Kelley, H. H. (1979). Personal Relationships: Their Structures and Processes. Hillsdale, NJ: Lawrence Erlbaum Associates.

Kohlleppel, T. C. (2002). Specialization, Motivation, and Constraints: What is the Garden Path? (Yayımlanmamış Doktora Tezi). University of Florida. (Yayın No. AAT 3084015).

Lee, S. H. ve Tideswell, C. (2005). Understanding Attitudes towards Leisure Travel and the Constraints Faced by Senior Koreans, Journal of Vacation Marketing, 11 (3): 249ᄀ-263.

Little, D. E. (2002). Women and Adventure Recreation: Reconstructing Leisure Constraints and Adventure Experiences to Negotiate Continuing Participation, Journal of Leisure Research. 34 (2): 157-177.

Livengood, J. S. ve Stodolska, M. (2004). The Effects of Discrimination and Constraints Negotiation on Leisure Behavior of American Muslims in the Post-September 11 America, Journal of Leisure Research, 36 (2): 183-208.
Assessing Hierarchical Leisure Constraints Theory after Two Decades

Lu, J. (2006). Perceived Constraints on Participating in Walking or Hiking Along the Trans Canada Trail. (Yayımlanmamış Doktora Tezi). University of Manitoba (Kanada). (Yayın No. AAT MR22555)

Mannell, R. C. ve Loucks-Atkinson, A. (2005). Why Don't People Do What's "Good" For Them? Cross-Fertilization among the Psychologies of Nonparticipation in Leisure, Health, and Exercise Behaviors. E. L Jackson (Ed.), Constraints to Leisure (ss. 221-ᄀ232). State College, PA: Venture.

McCarville, R. E. ve Smale, B. J. (1993). Perceived Constraints to Leisure Participation within Five Activity Domains, Journal of Park and Recreation Administration, 11 (2): 40-59.

McQuarrie, F. A. ve Jackson, E. L. (1996). Negotiation of Leisure Constraints and Serious Leisure: Exploring Connections in a Case Study of Adult Amateur Ice Skaters, Leisure and Society, 19: 459-483.

McQuarrie, F. A. ve Jackson, E. L. (2002). Transitions in Leisure Careers and Their Paralᄀlels in Work Careers: The Effect of Constraints on Choice and Action, Journal of Career Development, 29 (1): 37-53.

Mead, G. H. (1934). Mind, Self, And Society. Chicago: University of Chicago Press.

Nadirova, A. ve Jackson, E. L. (2000). Alternative Criterion Variables against which to Assess the Impacts of Constraints to Leisure, Journal of Leisure Research, 32 (4): 396-405.

Norman, W. (1995). Perceived Constraints: A New Approach to Segmenting the Vacation Travel Market. 1995 Symposium on Leisure Research Bildiri Özetleri (s. 113). Arlington, VA: National Recreation and Park Association.

Nyaupane, G. P. ve Andereck, K. L. (2008). Understanding Travel Constraints: Application and Extension of a Leisure Constraints Model, Journal of Travel Research, 46 (4): 433-440.

Nyaupane, G. P., Morais, D. B. ve Graefe, A. R. (2004). Nature Tourism Constraints: A Cross-Activity Comparison, Annals of Tourism Research, 31 (3): 540-555.

Oh, S. (2005). Successful Aging through Leisure Gardening: A Study on Constraints Negotiation. (Yayımlanmamış Doktora Tezi). The Pennsylvania State University. (Yayın No. AAT 3172993).

Oh, S. ve Caldwell, L. L. (1999). Examining Leisure Constraints among Older Adults Using the Theory of Selective Optimization and Compensation. Leisure Research Symposium Bildiri Kitabı: 59.

Pennington-Gray, L. ve Kerstetter, D. (2002). Testing a Constraints Model within the Context of Nature-Based Tourism, Journal of Travel Research, 40 (4): 416-423.

Petrick, J. F., Backman, S. J., Bixler, R. ve Norman, W. C. (2001). Analysis of Golfer Motivations and Constraints by Experience Use History, Journal of Leisure Research, 33 (1): 56-70.

Philipp, S. F. (1994). Racial Differences in Perceived Leisure Constraints, Perceptual and Motor Skills, 79 (3): 1339-1343.

Raymore, L. A., Godbey, G., Crawford, D. W. ve Von Eye, A. (1993). Nature and Process of Leisure Constraints: An Empirical Test, Leisure Sciences, 15: 99-113.

Raymore, L., Godbey, G. ve Crawford, D. (1994). Self-Esteem, Gender, and Socioeconomic Status: Their Relation to Perceptions of Constraint on Leisure among Adolescents, Journal of Leisure Research, 26 (2): 99-118.

Samdahl, D. M. ve Jekubovich, N. J. (1997). A Critique of Leisure Constraints: Comparative Analyses and Understandings, Journal of leisure Research, 29 (4): 430-452. 
Scott, D. (1991). The Problematic Nature of Participation in Contract Bridge: A Qualitative Study of Group-Related Constraints, Leisure Sciences, 1: 321-336.

Scott, D. ve Munson, W. (1994). Perceived Constraints to Park Usage among Individuals with Low Incomes, Journal of Park and Recreation Administration, 12: 79-96.

Scott, D. ve Jackson, E. L. (1996). Factors That Limit and Strategies That Might Encourage People's Use of Public Parks, Journal of Park and Recreation Administration, 14 (1): 1-11.

Searle, M. S. ve Brayley, R. E. (1992). Is Constrained Leisure an Internally Homogeneous Concept? A Further Examination, NRPA Symposium on Leisure Research, Cincinnati, Ohio.

Shaw, S. M. ve Henderson, K. (2005). Gender Analysis and Leisure Constraints: An Uneasy Alliance. E. L. Jackson (Ed.), Constraints to leisure (23-34). State College, PA: Venture.

Son J. S., Kerstetter, D. L. ve Mowen, A. J. (2008). Do Age and Gender Matter in the Constraint Negotiation of Physically Active Leisure?, Journal of Leisure Research, 40 (2): 267-289.

Stodolska, M. (1998). Assimilation and Leisure Constraints: Dynamics of Constraints on Leisure in Immigrant Populations, Journal of Leisure Research, 30 (4): 521-551.

Tian, S., Crompton, J. L. ve Witt, P. A. (1996). Integrating Constraints and Benefits to Identify Responsive Target Markets for Museum Attractions, Journal of Travel Research, 35 (2): 34-45.

Tsai, E. ve Fung, L. (2005). Perceived Constraints to Leisure Time Physical Activity Participation of Students with Hearing Impairment, Therapeutic Recreation Journal, 39 (3):192-206.

Walker, G. L. (2007). Multicultural Perspectives. R. McCarville ve K. MacKay (Ed). Leisure for Canadians (ss.155-161). State College, PA: Venture.

Walker, G. J., Deng, J. ve Dieser, R. B. (2005). Culture, SelfConstrual, and Leisure Theory and Practice, Journal of Leisure Research, 37: 77-99.
Walker, G. J., Jackson, E. L. ve Deng, J. (2007). Culture and Leisure Constraints: A Comparison of Canadian and Mainland Chinese University Students, Journal of Leisure Research, 39 (4): 567-590.

Walker, G. J., Jackson, E. J. ve Deng, J. (2008). The Role of SelfConstrual as an Intervening Variable between Culture and Leisure Constraints: A Comparison of Canadian and Mainland Chinese University Students, Journal of Leisure Research, 40 (1): 90-109.

Walker, G. ve Virden, R. (2005). Constraints on Outdoor Recreation. E. L. Jackson (Ed.), Constraints to Leisure (ss.201-219). State College, PA: Venture.

Williams, P. ve Fidgeon, P. R. (2000). Addressing Participation Constraint: A Case Study of Potential Skiers, Tourism Management, 21: 379-393.

Wright, B. A, ve Goodale, T. (1991). Beyond Non-Participation: Validation of Interest and Frequency of Participation Categories in Constraints Research, Journal of Leisure Research, 23: 314-331.

Wright, B. A., Drogin Rodgers, E. B. ve Backman, K. F. (2001). Assessing the Temporal Stability of Hunting Participation and the Structure and Intensity of Constraints: A Panel Study, Journal of Leisure Research, 33 (4): 450-469.

Xiong, F. (2007). Constraints on Leisure Activities Participation among Chinese Immigrants in Canada. Yüksek lisans tezi. Lakehead University, (Kanada). (Yayın No. AAT MR31872).

Young, S. J., Ross, C. M. ve Barcelona, R. J. (2003). Perceived Constraints by College Students to Participation in Campus Recreational Sports Programs, Recreational Sports Journal, 27 (2): 47-62.

Zhang, M. L. (2007). An Analysis of Recreational Golfer Motivation, Constraints, and Satisfaction on the Mastery and Frequency of Play in the Gulf Coast Region of Mississippi. (Yayımlanmamış Doktora Tezi). United States Sports Academy (Yayın No. AAT 3285712). 